\title{
Encouraging Technology Export through Public Financial Support
}

This chapter supplies the second of the two case studies that test out Common Concern inspired trade measures in practice. This study zooms in to the issue of access to finance - one of the key obstacles for the private sector to acquire emission reducing technologies. Within that perimeter, the current chapter focuses on the relationship of potential support measures with the Subsidies Agreement of the Wто - especially, the control it would exercise on potential enhancement of such measures. While the argument of boosting climate finance is considered as a virtuous one on the whole, the opaque issue is whether the cause would also justify unregulated public finance of private transactions in low-carbon technologies (LCT), particularly when involving developing country partners. This issue is explored in detail here.

The chapter begins with an outline of the need for additional public finance for technology outflows and proposes the enhancement of export promotion support as a positive contributor. The approaches thereof, i.e. supply of financial credit in better terms, or sharing of destination-specific risks are then examined in the backdrop of the trade regulation - the Agreement on Subsidies and Countervailing Measures (ASCM, or the SCM agreement), to be specific. Then the lens of Common Concern of Humankind is brought into play to identify areas of further development. The chapter explains that the promotion of clean technology exports and investments could be mutually beneficial for all parties involved. To that effect, the Common Concern doctrine can facilitate an accommodating understanding of the subsidies regulation, as well as indicate the pertinent areas of new rule-making. This conclusion however remains subject to one important caveat. While markets often lack public support boosting trade or investment flows in the LCT s, it may enjoy the same in the sectors that are harmful to the climate. A successful paradigm of financial assistance in the light of resolving the common concern of humankind should also include a parallel focus on the withdrawal of counterproductive supports existing on the market. 
We earlier noted how inadequate finance limits the success of the formal regulatory arrangements on technology transfer in the climate regime. ${ }^{827}$ In the technology needs assessment (TNA) reports, most developing countries identify non-availability of finance as the biggest problem. ${ }^{828}$ This is the context against which the need for augmentation of public financial support in this area must be assessed.

Despite its crucial importance, public share of total climate finance is not only minuscule, but its flow is also limited largely within developed countries. While the global total climate finance stood at somewhere between USD 456 and 681 billion in 2016,829 only about a third or even less of that amount (USD 157 billion) has travelled from the public and private sources in the developed countries to the developing destinations. ${ }^{830}$ Of the global total climate finance reported above, private financial flows, especially investment in renewable energy (USD 217 billion) and energy efficiency improvements (USD 224

827 See Chapter 2 II B at p. 67 and onwards.

828 See Chapter 2 III C at p. 85 above.

829 These numbers tend to vary largely due to disagreement on what counts towards climate finance and difference in approaches towards finding an aggregate number. This estimate is taken from the last biennial report (2018) prepared by the UNFCCC standing committee on finance. See UNFCCC, 'UNFCCC Standing Committee on Finance: 2018 Biennial Assessment and Overview of Climate Finance Flows Technical Report' (United Nations Climate Change Secretariat 2019) 55-58; For earlier estimates, see Sujata Gupta and others, 'Cross-Cutting Investment and Finance Issues', Climate change 2014: mitigation of climate change: Working Group III contribution to the Fifth Assessment Report of the Intergovernmental Panel on Climate Change (Cambridge University Press 2014) 1213-1214.

830 UNFCCC, 'UNFCCC Standing Committee on Finance: 2018 Biennial Assessment and Overview of Climate Finance Flows Technical Report' ibid 7o. This is a very rough estimate. Detailed data, especially those of the private financial flows, do not exist. Similar numbers are reported in the IPCC fifth assessment report, Gupta and others (n 832) 1234. This should not be confused with the 100 billion goal committed to in the Copenhagen Accord. For different takes on the latter, see OECD and Climate Policy Initiative, 'Climate Finance in 2013-14 and the USD 100 Billion Goal' (Organization for Economic Cooperation and Development (OECD) 2015) <https://www.oecd.org/environment/cc/OECD-CPIClimate-Finance-Report.pdf> accessed 25 October 2020; Climate Change Finance Unit, Ministry of Finance, Government of India, 'Climate Change Finance, Analysis of a Recent OECD Report: Some Credible Facts Needed' <https:/dea.gov.in/sites/default/files/ ClimateChangeOEFDReport_o.pdf $>$ accessed 25 October 2020; Mariama Williams, 'The State of Play of Climate Finance - UnfCcc Funds and the \$10o Billion Question' (South Centre 2019) $21<$ https://www.southcentre.int/wp-content/uploads/2019/12/CPB21_TheState-of-Play-of-Climate-Finance-UNFCCC-Funds-and-the-10o-Billion-Question_EN1.pdf $>$ accessed 25 October 2020 . 
billion) account for the lion's share. One estimate shows that public financial flows, comprised chiefly of finance through multilateral development banks, amounted to $34 \%$ of the total flow of climate finance in 2015 and $2016 .{ }^{831}$ The same report also indicates that almost $80 \%$ of the total volume of climate finance is domestically raised and spent, ${ }^{832}$ meaning that a relatively very small portion of that total flows to the developing countries. To illustrate, private foreign direct investment (FDI) flow to renewable energy projects in developing countries was USD 1.5 billion in 2016,833 whereas in the same year, the total amount of funds spent globally on energy access stood at USD 19.4 billion. ${ }^{834}$

Therefore, there is a strong case for improving public financial support, especially by the developed countries, for activities that result in the diffusion of LCT s to developing countries. Such support will be counted towards the fulfilment of the existing commitment of amassing USD 100 billion in new and additional finance. ${ }^{835}$ This would also be helpful in leveraging, as well as channelling private financial flows in the form of trade and investment transactions to locations that are otherwise unattractive in market terms. Domestically, such support can also open limited opportunities for green industrial policy. These issues are detailed below.

\section{A The Problem and Potential of Public Finance}

Public financial resources can be employed to cure the existing disincentives that prevent LCT spreading transactions from taking place. In cases where such transactions involve developed and developing country partners, public financial institutions of the developed country can be involved in ways that resolve the challenges of access to finance and other risk factors that would otherwise dissuade a private business entity. Such involvement corrects financial market failures and promises to augment the scale of transactions taking place.

Unaffordable prices and lack of adequate access to finance have already been highlighted as key barriers to low-carbon technology diffusion to developing countries. ${ }^{836}$ These issues divert crucial energy infrastructure investments to high-carbon options with disastrous impacts over the long-run. For

\footnotetext{
831 Barbara K Buchner and others, 'Global Landscape of Climate Finance 2017' (Climate Policy Initiative 2017) 4.

832 ibid 13 .

833 UNFCCC, 'UNFCCC Standing Committee on Finance: 2018 Biennial Assessment and Overview of Climate Finance Flows Technical Report' (n 832) 70.

834 Buchner and others (n 831) 7 .

835 This is the goal 13.a of the Sustainable Development Goals (SDG s). See United Nations General Assembly (n 210).

836 See Chapter 2 III C at p. 85 and onwards.
} 
example, the fifth IPCC assessment report predicted $78 \%$ of the upcoming investments in fossil fuel power plants to be taking place in non-OECD countries due to their relatively lower cost. ${ }^{837}$ While ideally the developing countries are deserving destinations for low-carbon investment, most, except maybe a few, are considered relatively high-risk countries for investment in general. ${ }^{838}$ This drives up the cost of capital, also the rate of return on investment desired by private investors. 839

In more detail, challenges to the enhancement of trade and investment flow to developing countries involve investment risks, insufficient returns, inadequate market size, difficulty to raise longer-term capital, capacity, and human resource constraints. ${ }^{840}$ The investment risks are manifested as risks due to the novelty of the technology, as well as risks arising from a specific locale - i.e. political and financial instability, rule of law problems etc. ${ }^{841}$ Combination of these different risks makes it difficult for a foreign investor in LCT find a suitable financial proposition for their lenders and equity partners. Moreover, raising fund from the developing country financial markets are also challenging because of the absence of a deep market that can ensure an adequate supply of funds over the long term. All of these factors contribute to a market failure where inadequate financial flows lead the developing countries to a highercarbon trajectory.

In a global financial landscape highlighted by the growing clout of private financial services, the role of public financial support in addressing the above risks are complementary in nature. Public financial engagement in the clean technology sectors can leverage the flows of private finance by sharing risks. Because public engagement decreases the volatility of the sectors, the rate of returns on investment in those sectors increase, which can then help crowd-in private investors as well. ${ }^{842}$ In parallel, allocation of public funds to the relatively risky ventures also leaves the traditional investment opportunities open

837 Gupta and others (n 829) 1217, 1236 .

838 See generally, 'Country Risk Classification - OECD' <https://www.oecd.org/trade/topics/ export-credits/arrangement-and-sector-understandings/financing-terms-and-conditions/ country-risk-classification/> accessed 25 October 2020; Also, 'Sovereign Risk Indicators S\&P Global Ratings' <https://www.spratings.com/sri/> accessed 25 October 2020.

839 Gupta and others (n 829) 1236.

840 ibid 1224-1226; For a different classification, see, Martin Stadelmann, Paula Castro and Axel Michaelowa, 'Mobilising Private Finance for Low-Carbon Development' (Climate Strategies 2011).

841 Stadelmann, Castro and Michaelowa, ibid 6; Gupta and others (n 829) 1225.

842 Stadelmann, Castro and Michaelowa (n 840). 
for private financing enterprises. ${ }^{843}$ Overall, when such measures are taken by developed country governments, they are on one hand helpful in sharing and thereby reducing the risks faced by their exporters of and investors in lowcarbon technologies. This additionally plays a role in reducing those countries' emission footprint from import consumption, a matter that remains so far unaddressed. ${ }^{844}$ Side by side, such measures can also provide the developing country markets with much-needed technology and also access to additional finance.

\section{B Possible Avenues of Public Support}

Following above, it is submitted that the appropriate public policy option to support private trade and investment transactions depend very much on the nature of the prevailing obstacles and the existing policy environment. Public financial support for LCT diffusion can take place in various ways. Development assistance is one of the channels where financial assistance takes place in non-market terms. Financial incentives can also potentially be supplied by providing tax credits. Exporters of LCT s or domestic investors investing in clean technology sectors abroad can be provided tax relief based on the evidence of successful technology diffusion. ${ }^{845}$ Two other options deal with addressing the financial constraints of the private actors engaged in clean technology related transactions. One way is to make necessary financial resources available to the relevant exporters, investors and related institutions at prevailing market rates, or even in better terms. The other option is for the government to help reduce the businesses' exposure to risks arising from the transactions. ${ }^{846}$ Both of these options contribute to lowering of the overall cost faced by the private firms in

843 John Ward and others, 'Catalysing Low-Carbon Growth in Developing Economies: Public Finance Mechanisms to Scale up Private Sector Investment in Climate Solutions' (UNEP and Partners 2009); Stadelmann, Castro and Michaelowa (n 840); Karsten Neuhoff, 'International Support for Low-Carbon Growth in Developing Countries', Climate policy after Copenhagen : the role of carbon pricing (Cambridge University Press 2011).

844 See pp. 20, \& 153 above.

845 Hoekman, Maskus and Saggi (n 611); Bernard Hoekman, Keith E Maskus and Kamal Saggi, 'Transfer of Technology to Developing Countries: Unilateral and Multilateral Policy Options' [2004] World Bank Policy Research Working Paper. It was proposed that as regional governments offer tax credits for companies to stay in technology poor areas, the central government can provide similar credits upon transfer of technology by a company abroad.

846 Traerup, Greersen and Kundsen (n 408) 16. In this recent synthesis of climate regime processes relevant to technology development and transfer, the authors highlight the potential of low interest credits, credit guarantees, improvement of access to international funds and other forms of incentives to get rid of technology diffusion barriers. 
doing business. Export promotion tools like the supply of credits, credit guarantees, and insurances fall within these categories. This is where the chapter's focus would remain.

Public financial supports, like export credits, are the mainstays of global finance, especially in the post-financial crisis era. Export credit activities include financial supports provided at specific fixed rates, or floating rates, as well as liquidity support like extension of grants. ${ }^{847}$ Instead of the actual supply of credits, the governments may also provide guarantees against default, thereby easing the businesses' opportunity to obtain finance from the private market. Governments may as well insure an exporter or investor against incurring risks abroad. One study gave the example of the Overseas Private Investment Corporation (OPIC) in the United States, which insures outward renewable energy investments against host government actions. ${ }^{848}$

These support measures are generally made available by countries to domestic exporters and investors irrespective of the nature of the transactions. Guided by a nationalist commercial motive, these work to enhance the comparative advantage of the domestic exporters. As a result, while there are instances of public agencies extensively supporting clean technology exports, ${ }^{849}$ same is also true for other areas, including some polluting ones. For example, between 2010 and 2016, two major Chinese public finance institutions spent approximately USD 16o billion in energy finance $-80 \%$ of which went in building power plants abroad. Most (90\%) of those power plants were of fossilfuelled type..$^{850}$

Investment promotion is one of the key ways by which public support can facilitate technology outflow. While much of the existing literature approaches

847 See for example, 'Our Solutions' (Export Finance Australia) <https://www.exportfinance.gov.au/about-us/our-solutions/> accessed 25 October 2020. Also, 'EDC Solutions' (Export Development Canada) <https://www.edc.ca/en/solutions.html> accessed 25 October $202 \mathrm{O}$.

848 UN Environment Inquiry and Columbia Center on Sustainable Investment, 'Green Foreign Direct Investment in Developing Countries' (United Nations Environment Programme (UNEP) 2017) 25 < http://unepinquiry.org/wp-content/uploads/2017/10/Green_Foreign_ Direct_Investment_in_Developing_Countries.pdf .> accessed 25 October 2020.

849 R Jachnik and others, 'Tracking Climate-Related Export Credits: Existing Official Reporting Practices, Illustration of Methodological Options and Implications through Project Examples' [2017] Working document prepared for the Research Collaborative on Tracking Private Climate Finance 8-16.

850 UN Environment Inquiry and Columbia Center on Sustainable Investment (n 848) 26. Chinese investment also tends to crowd out private firms. See Hong Ru, 'Government Credit, a Double-Edged Sword: Evidence from the China Development Bank' (2018) 73 The Journal of Finance 275 . 
the issue of green investment promotion from a host-state perspective, ${ }^{851}$ home country incentives find only occasional limelight. ${ }^{852}$ From the perspective of fostering outwards foreign direct investment (OFDI), the measures such as those mentioned above will allow home country firms to take benefit of advantages in other destinations, achieve further specialisation, and bring back revenue, as well as tangible and intangible skills. ${ }^{853}$ It can be expected that financial incentives will encourage the domestic firms to furnish better technologies to their subsidiaries, and also search for suitable partners abroad. It should, however, be kept in mind that financial incentives are not the sole determiner for investment outflows. Investment outflow is influenced by various factors, which are not only comprised of those of the home country but also of host country characteristics, e.g. including macroeconomic stability, availability of desirable skills or factors, robust infrastructure etc. Therefore it is important to make sure that the incentives are open-ended so that the domestic firms can combine them with respect to their chosen country of investment.

In addition to triggering of greenfield investment in LCT sectors across borders, public finance can support domestic exporters in one-off technology transactions as well. Export credits will bridge the finance gap between the seller and the buyer; by allowing the buyer flexibility in terms of payment, and enabling the seller opportunity to recoup the investment in time. ${ }^{854}$ Credits, guarantees, and insurances would enable exporters of clean technology to expand supply to newer markets, including those in the low-income economies.

\section{The Promise and Challenge of the Export Credit Agencies (ECAs)}

Public financing of export is generally done either through export credit agencies (ECA S), or specially instituted banks (e.g. Export Import Banks). ${ }^{855}$ The

851 For example, UnCTAD, 'Promoting Low-Carbon Investment' (United Nations 2013) Series A, number 7; Martin Dietrich Brauch and Aaron Cosbey, Vehicles, Availability, and Governance of International Public Finance for Climate-Friendly Investment (International Institute for Sustainable Development 2012); Ravindra Ratnayake, Marc Proksch and Mia Mikić, Climate-Smart Trade and Investment in Asia and the Pacific: Towards a Triple-Win Outcome (ESCAP 2011).

$85^{2}$ Karl P Sauvant and others, 'Trends in FDI, Home Country Measures and Competitive Neutrality' in Andrea K Bjorklund (ed), Yearbook on International Investment Law and Policy (Oxford University Press 2012).

853 Jan Knoerich, 'How Does Outward Foreign Direct Investment Contribute to Economic Development in Less Advanced Home Countries?' (2017) 45 Oxford Development Studies 443 .

854 Marc Auboin, 'Improving the Availability of Trade Finance in Developing Countries: An Assessment of Remaining Gaps' (WTO 2015) Staff Working Paper ERSD-2015-06 3.

855 Here we use the term export credit agency (ECA) to cover both. 
general rationale behind such engagement is not to compete with the sphere of commercial lending, rather complementing it to secure additional export growth. ${ }^{856}$ Prior to the financial crisis, this motivation was becoming growingly questionable due to expansions in depth and coverage of private finance. ${ }^{857}$ However, since the crisis, the slowing of commercial lending activities has led to widespread calls for stepping up public financing to maintain trade transactions at 'business as usual' levels. The crisis has even prompted the WTO to encourage increased ECA activity, despite the possibility of triggering member states' behaviour verging on illegal subsidisation. ${ }^{858}$

Technically speaking, there are no binding international law controlling the actions of the ECAs, although they are entities established by the states. There is however a soft law framework in the form of the OECD Arrangement on Officially Supported Export Credits (hereafter 'the arrangement', Box 4). The arrangement has a unique and special relationship with the SCM agreement. ${ }^{859}$ Compliance with the arrangement provisions is required from the participants thereof, which is limited to the oECD member countries. ${ }^{860}$ Some of the arrangement provisions are also indispensable for all the што members seeking to engage in the export promotion activities, as will be detailed later. Apart from the arrangement, there are other, less detailed alternative platforms that work to coordinate the activities of the ECAs. Such platforms include the Berne Union ${ }^{861}$ and the International Working Group (IWG) on

$85^{6}$ Jian-Ye Wang and others, Officially Supported Export Credits in a Changing World (International Monetary Fund 2005) 5 .

857 ibid 10-13.

858 Auboin (n 854).

859 In the broader context of international attempts at disciplining artificial supports to the exports, this relationship go far back - even before the currently existing organizations (i.e. OECD and the WTO). A list of prohibited subsidies was agreed at the Organization for European Economic Cooperation (OEEC), and was later inherited by the OECD. The list was later appended to the GatT Tokyo Round (1973-1979) Subsidies Code. Meanwhile, as the oECD arrangement came to being (see box above), an exception was introduced to the list. The WTO subsidies agreement inherited that list. Andrew M Moravcsik, 'Disciplining Trade Finance: The OECD Export Credit arrangement' (1989) 43 International Organization 173; Dominic Coppens, 'Rationale for Disciplining Export Credit Support: Historical Context', WTO disciplines on subsidies and countervailing measures: balancing policy space and legal constraints (Cambridge University Press 2014) 349-355.

860 Current participants are Australia, Canada, the European Union, Japan, Korea, New Zealand, Norway, Switzerland, Turkey, and the United States. oECD, 'Export Credits' $<$ https://www.oecd.org/trade/topics/export-credits/> accessed 25 October 2020.

861 The Berne Union is a network of 85 export credit agencies, most of which are government linked. 'Berne Union - About the Berne Union' < https://www.berneunion.org/Stub/ Display/8> accessed 25 October 2020. 
export credits. ${ }^{862}$ Unlike the arrangement, wTO rules do not take account of these emerging platforms, although the latter often bring more developing country participation.

\section{Box 4: The OECD Arrangement}

\section{Arrangement on Officially Supported Export Credits}

The OECD arrangement is, as Wang and others have put, a "gentlemen's agreement among its participants; it is not an OECD act". ${ }^{863}$ It is an evolving document ${ }^{864}$ that lays down the general terms of official finance for the participating countries. According to its provisions, official support can either be financing support (i.e. direct credit, or interest rate support), or pure cover (i.e. insurance, or guarantee). The arrangement also welcomes compliance by non-participants.

The goal of the arrangement is to prevent participants from competing in a race to the bottom regarding offered terms of export credit. 865 To achieve that, the arrangement suggests rules on maximum repayment terms, down payment limits, minimum interest rates to be charged for fixed-rate finance (CIRR), ${ }^{866}$ and minimum premium rates for risk finance (MPR $)^{867}$. The arrangement also accepts the possibility of financing at floating rates, which may in some cases dip below the CIRR, depending on the market situation. ${ }^{868}$ Compliance with the provisions

862 The International Working Group (IWG) on Export Credits was established on a joint initiative by the United States and China. Its aim is to develop rules that cover not only OECD countries but also emerging countries like the BRICS.

863 Wang and others (n 856) 31 .

864 The version in effect at the time of writing this chapter is the one dated 1 January, 2018.

865 Article 1, OECD, 'arrangement on Officially Supported Export Credits' (OECD 2O18) TAD/ PG(2018)1.

866 These rates are known as 'commercial interest reference rates' (CIRR). The CIRR s are generally set in the participants' currencies, as 100 basis points $(1 \%)$ above a chosen base rate. The latter is derived from the yield of 3,5 , or 7 years government bonds issued by a participant. Overall, it ensures that while lending in its own currency, the government does not incur costs that cannot be recuperated. See Articles 19-22, ibid.

867 The participants are required to charge the minimum premium rates (MPR s) as a return for the risk coverage. The MPR s are determined taking into account several factors - (i) country risk classification, (ii) time at risk ('risk horizon'), (iii) buyer risk category, (iv) the percentage of political and commercial risk cover, (v) applied techniques of country risk mitigation, and (vi) applied buyer credit risk enhancements. See Articles 24-27 \& Annex IX, ibid.

868 It is to be noted however that with respect to floating rate finance scheme the short-term market rate will be applicable. The recipient institution are proscribed from the choice of option between the market rate and the CIRR. Article 22, ibid. 
of the arrangement is ensured through 'matching'869 - a measure that allows a competitor to match the terms offered by a participant or a nonparticipant, despite those terms being in breach of the agreed rules.

Among the sector-specific special rules (termed 'understanding') that are appended to the arrangement, one set deals with renewable energy, climate mitigation and adaptation, and water projects. ${ }^{870}$ Special minimum interest rates apply to the designated activities falling within the scope of the understanding. The scope of the designated activities leaves out many of the low-carbon technologies, while including fossil fuelbased power plants incorporating carbon capture technology.

The portrayal of the ECAs as climate benefactors can also be challenging due to the phenomenon described by an early report by the World Resources Institute (WRI) as 'policy perversity'. 871 While the countries commit to climate mitigation, their ECAs are run with the sole motivation of the promotion of domestic interests in commercial terms. As a result, not only is there an absence of climate, or environmental protection motivation, in real terms, a large portion of the ECA finance goes to polluting sectors. The WRI report indicated that fossil fuel power generation, oil, and gas sectors account for $40 \%$ of the public finance flowing from the developed to the developing countries. ${ }^{872}$ The earlier example of massive Chinese financial support for building coal-fired power plants abroad should also be recalled. ${ }^{873}$ In 2013, USD 1391 million of OECD export finance went to renewable electricity generation sector in the middle and low-income countries. ${ }^{874}$ The same figure for fossil fuel power plants that year was USD 2464 million. 875

Another issue with the current track record of the ECA s is the absence of transparency. The transactions and terms offered by the ECA s are often kept confidential. The participants to the arrangement report their activities to the OECD, but detailed information is either not reported or not regularly published by the organisation. In addition to business confidentiality, additional

\footnotetext{
869 Article 18, ibid.

870 Annex IV, ibid.

871 Crescencia Maurer and Ruchi Bhandari, 'Climate Notes: The Climate of Export Credit Agencies' (World Resources Institute 2000).

872 ibid 5-7.

873 See note 85 o above.

874 OECD, 'Statistics on Arrangement Official Export Credit Support for Electric Power Generation Projects' TAD/ECG(2015)10/FINAL 6.

875 ibid.
} 
reasons behind such non-transparency could possibly be a desire to hide nonpopular supports, as well as to be immune from export subsidisation claims. ${ }^{876}$

In addition, despite the ECA s putative role as financiers of ventures that are conventionally deemed as risky, relatively very little goes to support transactions involving partners from low-income countries. According to the OECD, in 2015 , about $5 \%$ of the overall official non-ODA finance support went to LDC $s$ and low-income countries. ${ }^{877}$ The aforementioned transparency problem also makes it difficult to determine how much of it can actually be considered to be in support of climate mitigation. According to the available figures on the OECD arrangement, much of the financial support for electricity generation projects goes to fossil fuel projects. ${ }^{878}$

\section{The Proposed Measure}

Simply put, we propose that the ECAs should prioritise financing transactions that enable the diffusion of climate technologies. Within that context, supports in better than market terms must be extended to trade or investment transactions involving developing or least-developed country partners - transactions which would not otherwise materialise due to capital market failures in the technology destination regions. It is also proposed that the minimum interest rates currently applicable under the OECD arrangement be relaxed to the extent commercially viable, when the transaction tangibly benefits developing countries' clean technology access. To a degree, downward competition in offered terms of finance among the developed country ECA s regarding climate technologies can be desirable.

As the proposal made above is a part of the earlier detailed technology diffusion narrative, ${ }^{879}$ the goal here is to create win-win consequences for the involved parties. The proposed measure will benefit the suppliers of LCT s by enabling business growth and market access. Similarly, it would help partially address the developing and least-developed country firms' problems of

876 Thomas Wenidoppler, 'ECAs Go to Market: A Critical Review of Transparency and Sustainability at Seven Export Credit Agencies in Central and Eastern Europe' (Finance and Trade Watch, CEE Bankwatch Network 2017).

877 OECD, 'Non-ODA Flows to Developing Countries: Export Credits' < http://www.oecd.org/ dac/stats/beyond-oda-export-credits.htm > accessed 25 October 2020.

878 OECD, 'Statistics on Arrangement Official Export Credit Support for Electric Power Generation Projects' (n 874). On a further detailed level, the numbers on fossil fuel based electricity generation is dominated by support coming from Germany, Japan, Korea, and the United States; whereas, the same for renewables is contributed to a large extent by Germany and Denmark.

879 See Chapter 3 II A above. 
technology affordability and finance. Mechanisms as such can also cater to the additional growth in LCT demand resulting from the proposed carbon pricing measure in the foregoing chapter. ${ }^{880}$ The revenue recycling component of the pricing measure discussed in that connection can also serve as the source of finance to offer better credit terms to the developing countries. To the extent the LDC s are at the receiving end of the publicly supported technology transactions, the activities could be reported by the developed countries as partial fulfilment of their obligation to transfer technology under the TRIPS Article 66.2.

However, for such a proposition to be successful, it is important that the public financial supports are undertaken in a complementary manner. First of all, support for export and outward investments regarding LCT s must take place in conjunction with withdrawal from counterproductive engagements (e.g. financing coal power plants, or subsidising fossil fuels). Second, financial incentives for the facilitation of LCT transactions are supply-side solutions. For it to work, there must be effective demand in the receiving sector, itself depending upon an effective carbon price implemented domestically (e.g. possibly through a tax as discussed in the previous case study). Furthermore, countries seeking low-carbon technologies must also work to create an overall enabling regulatory environment by, among others, gradually reducing risks to foreign investments. This involves improvement of rule of law institutions, political stability, development of endogenous capacity, and improvement of adaptive skills. ${ }^{881}$

To sum up this section, increasing public financial support would play a direct and positive role to boost exports of and outward investments in LCT sectors. Such supports can be extended in the form of supplying credits, grants, and risk-sharing measures. Although these tools are useful in practice, a key challenge is that the export credit agencies (ECAs) that are in charge of deploying them, do not generally operate under a climate protection mandate. Moreover, the practice of official export credits does not have any applicable international law. While there is the non-binding OECD arrangement, its participants are mainly developed countries. Also, its coverage of climate-related projects falls short of including all forms of LCT transactions. Therefore, as a part of the homework obligation under the doctrine of Common Concern of Humankind, developed country governments, as well as other technology leaders need to provide public financial incentives to promote LCT transactions with the developing countries. Such efforts are beneficial for all the parties

880 See Chapter 4 I D above.

881 UNFCCC, 'UNFCCC Standing Committee on Finance: 2018 Biennial Assessment and Overview of Climate Finance Flows Technical Report' (n 829) 12, 100. 
involved. However, in addition to enhancing the volume of transactions in low-carbon technologies, complementary actions are also required, including withdrawal of supports running counter to the motive of climate protection.

Next, the compatibility of the proposed measure and its challenges with respect to the wто Agreement on Subsidies and Countervailing Measures (АSСM) are assessed below.

Although increasing export credit supports for clean technology diffusion are often prescribed, its relationship with the wTо laws, especially the SCM agreement is less looked into. ${ }^{882}$ Financial assistance, provided by the government to its firms through the ECAs, can indeed boost low-carbon technology transactions. But the possibility of effectively doing so without breaching the provisions of the SCM agreement is questionable. Lack of experts' attention to this issue can either be due to a tacit understanding of the unresolved relationship between export credits and subsidies, or possibly be due to a recent paucity in actual trade disputes brought by members in this regard. ${ }^{883}$

Wто law, in particular, the SCM agreement, also the earlier GATT Articles VI and XVI, are attracted in situations where a government financial support has potentially trade distortive effects. The ASCM controls subsidies that affect trade relationship, even outright prohibiting some forms of supports, e.g. most export subsidies. In essence, the SCM agreement represents a consensual balance struck

882 Literature on green subsidies and trade is vast, which makes the absence of discussion on export credits even more conspicuous. A sample of the influential literature on the topic, presented here, do not address the issue, Steve Charnovitz, 'Green Subsidies and the Wто' [2014] World Bank Policy Research Working Paper <http://documents.worldbank.org/curated/en/2014/10/2029o817/green-subsidies-wto > accessed 25 October 2020; Bradly J Condon, 'Disciplining Clean Energy Subsidies to Speed the Transition to a LowCarbon World' (2017) 51 Journal of World Trade 675; Ilaria Espa and Gracia Marín Durán, 'Renewable Energy Subsidies and wто Law: Time to Rethink the Case for Reform Beyond Canada - Renewable Energy/Fit Program' [2018] Journal of International Economic Law; Luca Rubini, 'Ain't Wastin' Time No More: Subsidies for Renewable Energy, The scm agreement, Policy Space, and Law Reform' (2012) 15 Journal of International Economic Law 525; Gary Horlick and Peggy A Clarke, 'Rethinking Subsidy Disciplines for the Future: Policy Options for Reform' (2017) 20 Journal of International Economic Law 673 .

883 Since the tussle between Embraer of Brazil and Bombardier of Canada pursued by the respective governments in the early years of the wTо, the provisions relating export credits have not been much contested. One exception the Korea-Measures Affecting Trade in Commercial Vessels (DS 273) dispute decided in 2005. 
by the што members between distortive subsidisation and domestic interest protection. As the bargain is politically struck, the rationale underlying the agreement is not always economically optimal. It is especially true with respect to the areas where existing market failures justify subsidisation from an economic point of view, but the current rules will prohibit such steps.

Initially, the SCM agreement had a framework resembling a traffic lights approach, protecting certain subsidies from being challenged, ${ }^{884}$ while outright prohibiting certain others. ${ }^{885}$ In between, there were subsidies that could be challenged in a dispute provided that those resulted in some form of 'adverse effect'. ${ }^{886}$ Since the lapse of Article 8 of the agreement there are no protected subsidies (i.e. non-actionable subsidies). ${ }^{887}$ While the prohibited subsidies can be challenged in a dispute by any members, the 'adverse effects' can be challenged by the members who are impacted thereby. ${ }^{88}$ In addition, the member into whose territory subsidised products are imported, can also initiate an investigation to determine the margin of 'injury' to the domestic industry. Upon a positive finding, the aforementioned member is allowed to impose a countervailing duty (CVD) against the exporting member. ${ }^{889}$

While the proposed measure in the previous section is motivated by the importance of public financial support for low-carbon technology diffusion, the WTO law must play a role to make sure that the supports do not become an excuse for unnecessarily distortive industrial policies, in particular harming the growth of new industries in the developing countries. As a result, it is important to retain the essence of the earlier mentioned balance in the SCM agreement between public support and trade distortion. To do so, while allowing for opportunities to promote clean technology transactions, is a quest to find a threshold beyond which a capital market failures resulting in lingering common concerns should be intervened by the governments. Where that threshold

884 Article 8, Non-Actionable Subsidies, Agreement on Subsidies and Countervailing Measures (n 434). It should be noted that the provision did not save subsidies that were designated as prohibited.

885 Article 3, ibid.

886 Articles $5^{-7}$, ibid. The categories of adverse effects are: (i) injury to domestic industry, (ii) nullification or impairment of benefit accrued under the GATT 1994, and (iii) serious prejudice.

887 Article 8 was the outcome of a successful bargain driven by the EU, Canada and Mexico. It lapsed in 1999, along with the other part of the bargain, i.e. Article 6.1 of the Subsidies Agreement. See Coppens, WTO Disciplines on Subsidies and Countervailing Measures (n 440) $187-188$.

888 Articles 4.1 and 7.1, Agreement on Subsidies and Countervailing Measures (n 434).

889 Article vi, General Agreement on Tariffs and Trade (n 426); Articles 10-11, Agreement on Subsidies and Countervailing Measures (n 434). 
would lie depends on the extent to which the current subsidy rules allow or prohibit the proposed steps. Following paragraphs elucidate that point.

\section{A The Key Questions}

The key sticking points regarding the compatibility of enhanced ECA support for clean technology finance with the SCM agreement can be ordered in accordance with the structure of the agreement itself. At the outset, the question would be to what extent the envisaged ECA measures would come under the coverage of the ASCM. Second, with regard to the transactions that may fall within the agreement's scope, the issue would be how the agreement may deal with those.

The coverage of the ASCM is determined by Article 1 of that agreement. Simply put, the provision holds that any 'benefit' conferring 'financial contribution', coming from the government or a public body, or private entities 'entrusted or directed' by the former are within the scope of the agreement. Whether the SCM rules would cover the matters regarding promotion of LCT s or not would primarily hinge on the question whether such measures are considerable as conferment of benefit upon the recipient. If so, then rest of the Agreement provisions would come into play. Another issue would be the dividing line between trade and investment, raising the question whether identical measures promoting investment rather than export would also fall within the SCM agreement's scope or not.

ECA support measures that fall within the boundaries of the ASCM raise two further questions. One is the extent to which the agreement would altogether prohibit support measures of such form. The agreement clearly disallows subsidies that are contingent, either in law or in fact, upon export performance. ${ }^{890}$ While compliance with the OECD arrangement by a support measure provide limited cover from the prohibition, ${ }^{891}$ the question would be whether that is sufficient or useful at all. Furthermore, even when an ECA support for LCT diffusion is not found as manifestly illegal and subject to immediate withdrawal, there is the possibility that third-party wто members may challenge such financial supports on the ground of those being 'specific's92 and resulting in price distortions or displacement of the share of their exports in the receiving country market. ${ }^{893}$

890 Article 3, Agreement on Subsidies and Countervailing Measures (n 434).

891 The second paragraph of item ' $\mathrm{k}$ ' in the illustrative list of export subsidies, Annex I, ibid.

892 Article 2, ibid.

893 Serious prejudice, as per Article 5, ibid. 
Given the fact that the proposed approaches attempt to facilitate LCT related exports and investments in a mutually beneficial fashion, it is not foreseen that the receiving country itself may object to such actions by the incentivising country. However, in the absence of a shared understanding to that effect, in case such measures are found as a subsidy, they may also be challenged by the receiving country in a dispute or through an injury investigation followed by the imposition of CVDs. As it is not considered forthcoming, we will refrain from that analysis.

The following paragraphs elaborate on these questions.

\section{B Scope of the Agreement}

The subject-matter scope of the SCM agreement is determined by the definition of a 'subsidy' as laid out in Article 1.1 therein. Accordingly, a subsidy exists when a benefit is conferred either by a financial contribution, or an income or price support. With respect to the measures under analysis, i.e. export credits and guarantees in different forms, the pertinent questions are, first, whether these are considerable as financial contributions; and second, if so, whether they confer benefit within the meaning of the ASCM. ${ }^{894}$

Financial Contribution by a Government or Public Body [...]

Among the different avenues of support that are listed under Article 1.1(a)(1) of the SCM agreement, one explicitly covers credits and guarantees. The first item of that list is, "a government practice [that] involves a direct transfer of funds (e.g. grants, loans, and equity infusion), potential direct transfers of funds or liabilities (e.g. loan guarantees)". Different forms of export credit support for LCT diffusion would exactly fit this description. ${ }^{895}$ Direct support measures such as export credit or interest rate support would be considered as actual transfer of funds. For example, in the Japan - DRAM s (Korea) the Appellate Body ( $\mathrm{AB})$ opined that the transactions that are similar to the ones given example of in the list are covered by the list scope. ${ }^{896}$ In the Brazil - Aircraft dispute that involved interest rate support payment made by the Respondent to the institutions extending the export credit, it was not even contested that such

894 We do not explore the income and price support route because it is arguably a long stretch, for reasons below, to think that credit or guarantees would be found as such instead of financial contribution.

895 Dominic Coppens, 'Disciplines on Export Credit Support for Non-Agricultural Products', WTO disciplines on subsidies and countervailing measures: balancing policy space and legal constraints (Cambridge University Press 2014) 361-362.

896 Japan - Countervailing Duties on Dynamic Random Access Memories from Korea [2007] Appellate Body Report WT/DS336/AB/R, DSR 2007:VII 2703 [250-252]. 
supports are subsidies. ${ }^{897}$ Pure cover supports, e.g. risk insurance or credit guarantees would be considered as a potential transfer of funds. Furthermore, to be considered as a financial contribution, it is not required for such transfers to be actually carried out. ${ }^{898}$ It should also be noted that it is the actual measure by the government that fall suspect. So, in cases where the ECA s directly extend the support instead of going through a financial intermediary (e.g. a bank), then the transaction itself can be considered as a financial contribution. Similarly, in a situation where the government supports an intermediary to provide a guarantee or credit, it is the government support and not the credit itself that falls under the coverage of subsidy consideration.

Additionally, the subsidy definition requires that the putative financial contribution must also have a linkage with a government apparatus. Therefore, among the different types of export credits and guarantees supplied in the market by the private financial entities, multilateral development banks, as well as public institutions, which will fall within the scope of the Sсм agreement depends on the wording of the provision on one hand and actual characteristics of the transaction on the other. Article 1.1(a)(1) specifies that the provider of support must be one of the three following - the government itself, or a public body within the domestic territorial domain, or even a private entity that is required by the government to provide such contribution as part of the governmental activity. Keeping this in view, support by the ECA s is indeed considerable as provided by the government or public body. ${ }^{899}$ Support by private financial institutions would not automatically be so considered, as long as the private institution has no relationship with the government. However, it has been decided with respect to one dispute that the extent to which government or public support enables a private financial institution to supply export credits, the support itself would be considered a financial contribution. ${ }^{900}$

897 Brazil - Export Financing Programme for Aircraft [1999] Panel Report WT/DS46/R, DSR 1999:III 1121 7.12-7.14; For more, see United States - Measures Affecting Trade in Large Civil Aircraft (Second Complaint) [2012] Appellate Body Report WT/DS353/AB/R, DSR 2012:I 7 616, 620 .

898 Brazil - Export Financing Programme for Aircraft (n 9oo) 7.13; European Communities and Certain Member States - Measures Affecting Trade in Large Civil Aircraft [2011] Panel Report WT/DS316/R, DSR 2011:II 685 7.302.

899 Canada - Export Credits and Loan Guarantees for Regional Aircraft [2002] Panel Report WT/DS222/R, DSR 2002:III 849 [7.62, 7.66]. The Respondent Canada did not dispute that financial support provided to Bombardier through its ECA, i.e. the Export Development Corporation (EDC) amounted to financial contribution within the meaning of ASCM Article 1.

900 Brazil - Export Financing Programme for Aircraft (n 897) para 7.12-7.13. Although the exporter received support through financial intermediaries, the Panel did not find 
While in most cases, as mentioned above, the finding of official export credit support as a financial contribution would be straightforward, some ambiguous questions can indeed arise. One such is the issue of characterising the nature of support extended through state-owned enterprises (SOE s) or stateowned commercial banks (sосв s). While such entities are not government itself, they could be considered as a 'public body'. However, such characterisation, according to the Appellate Body, must comprise of a careful and detailed, fact-based exercise to determine whether the entity "possesses, exercises, or is vested with governmental authority". ${ }^{901}$ There must be "formal indicia of government control, [and] evidence that such control has been exercised in a meaningful way" ${ }^{\prime 92}$ In absence of such evidence, the entities, even if substantially owned by the government, cannot be considered as a 'public body'. Mere policy pronouncements or situations where the private entities conduct is a by-product and not a result of government action is not sufficient. ${ }^{903}$

To sum up, export support activities by the ECAs would in most cases, in a straightforward fashion, be termed as a subsidy within the meaning of the sCM agreement. While covering government support, the agreement will, in all probability, also bring under its cover the activities of state-owned commercial entities, when providing similar natured supports to spread LCT s across borders. Whether the latter would be the case depends on various surrounding factors pertaining to the relationship between the government and the entity in question. There may be some opportunity to hide a support measure behind

it worthwhile to specify how it amounts as a subsidy. According to the Panel, the contested measure 'fulfils the definition of a subsidy because there is a government practice, whether it involves a direct transfer of funds -- as Canada believes -- or a potential direct transfer of funds - as Brazil believes. As soon as there is such a practice, a subsidy exists, and the question whether the practice involves a direct transfer of funds or a potential direct transfer of funds is not relevant to the existence of a subsidy'. [para 7.13].

901 United States - Definitive Anti-Dumping and Countervailing Duties on Certain Products from China [2011] Appellate Body Report WT/DS379/AB/R, DSR 2011:V 2869 [317, also 288, 290, and 310].

902 ibid 318. Also note para 319: "[i]n all instances, panels and investigating authorities are called upon to engage in a careful evaluation of the entity in question and to identify its common features and relationship with government in the narrow sense, having regard, in particular, to whether the entity exercises authority on behalf of government. An investigating authority must, in making its determination, evaluate and give due consideration to all relevant characteristics of the entity and, in reaching its ultimate determination as to how that entity should be characterised, avoid focusing exclusively or unduly on any single characteristic without affording due consideration to others that may be relevant".

903 United States - Countervailing Duty Investigation on Dynamic Random Access Memory Semiconductors (DRAMS) from Korea [2005] Appellate Body Report WT/DS296/AB/R, DSR 2005:XVI 8131 114. 
non-transparent relationship between the government and an SOE, but this will not be sustainable in the long run.

\section{Determination of Benefit}

The finding of benefit being conferred as a result of financial contribution is an examination that compares different situations of the recipient before and after the contribution. The pivotal question to be answered is whether the financial support has rendered the recipient better off than the entity would otherwise have been. Whether the provider has incurred costs in doing so is irrelevant. With respect to export credit practice, one of the very early Wто panel dealing with the issue opined that when government support enables a domestic producer to offer better terms of finance to the purchaser, benefit can be considered to exist prima facie. ${ }^{904}$

Also, the exercise of benefit analysis takes place in the context of the existing market conditions. In the Canada - Aircraft dispute the AB endorsed the Panel finding that a financial contribution confers 'benefit' when "it is provided on terms more advantageous than those that would have been available to the recipient on the market". ${ }^{905}$ Markets, according to the АВ are "the area of economic activity in which buyers and sellers come together and the forces of supply and demand affect prices." 906 Defining the bounds of the relevant market, and finding an appropriate benchmark therein has, over time, emerged as a crucial point of determination.

Regarding the abovementioned use of a benchmark, Article 14 of the SCM agreement, detailing benchmark calculation guidelines for CVD investigations, is relevant as an interpretative context of Article $1 .{ }^{907}$ It provides for different methods to determine the benchmark in the various settings of financial

904 Brazil - Export Financing Programme for Aircraft - Second Recourse by Canada to Article 21.5 of the DSU [2001] Panel Report WT/DS46/RW/2, DSR 2001:IX 5481 41, 42; Coppens, 'Disciplines on Export Credit Support for Non-Agricultural Products' (n 895) 363.

905 Canada-Measures Affecting the Export of Civilian Aircraft [1999] Panel Report WT/DS70/ R, DSR 1999:IV 1443 [9.112]; Canada - Measures Affecting the Export of Civilian Aircraft [1999] Appellate Body Report WT/DS70/AB/R, DSR 1999:III 1377 [157, 158]. The standard latter became know as the 'private market test'.

906 United States - Subsidies on Upland Cotton [2005] Appellate Body Report WT/DS267/AB/ R, DSR 2005:I 3 [7.1236]; European Communities and Certain Member States - Measures Affecting Trade in Large Civil Aircraft - Recourse to Article 21.5 of the DSU by the Unites States [2018] Appellate Body Report WT/DS316/AB/RW 1259.

907 Japan - Countervailing Duties on Dynamic Random Access Memories from Korea [2007] Panel Report WT/DS336/R, DSR 2007:VII 2805 7.275; Canada-Certain Measures Affecting the Renewable Energy Generation Sector / Canada-Measures Relating to the Feed-in Tariff Program (n 500) para 5.130. 
contribution. Three of the four methods supplied in Article 14 cover equity support, loan and loan guarantee relate to Article 1.1(a)(1)(i) - the list item covering export credit practices.

\section{a) Identifying the Relevant Market: Simple Conclusion}

A possible straightforward conclusion regarding the finding of benefit can be that it exists any time official support is provided to complement the capacity failure of private financial markets in facilitating transactions involving LCT s. ${ }^{908}$ The underlying argument is that these are transactions that would not otherwise take place in private market terms. We can also recall that the key reason behind our proposition is to enable exporters to engage in transactions that are not feasible under the current conditions of the market. If the contexts paragraph (b) or (c) of Article 14, as appropriate, is taken into account, the conclusion would point in the same direction. In both of those provisions, the support in question, i.e. a loan or a guarantee, is suggested to be assessed against the terms of a comparable commercial loan in the market. ${ }^{909}$ So, the cases where instances of a comparable commercial support measure do not exist, or in other words, is not offered by any private operators, it would appear conclusive that the terms offered by the government to support LCT transactions are beneficial to the recipient.

\section{b) Alternate Conclusion: Distorted Market Argument}

In contrast to the straightforward conclusion above, it is submitted that some previous disputes have also taken account of situations where the private market test is difficult to apply due to the absence of an undistorted benchmark. For example, in the United States - Softwood Lumber IV dispute, reference prices that could be obtained in the domestic market were found to be distorted. The question was, in context of Article 14 (d) of the SCM agreement, ${ }^{910}$

908 Coppens, 'Disciplines on Export Credit Support for Non-Agricultural Products' (n 895) $366-367$.

909 Paragraph (b) provides that "a loan [...] shall not be considered as conferring a benefit, unless there is a difference between the amount that the firm receiving the loan pays on the government loan and the amount the firm would pay on a comparable commercial loan which the firm could actually obtain on the market."

Paragraph (c) provides that "a loan guarantee [...] shall not be considered as conferring a benefit, unless there is a difference between the amount that the firm receiving the guarantee pays on a loan guaranteed by the government and the amount that the firm would pay on a comparable commercial loan absent the government guarantee." [emphasis supplied]

910 In situations where a government supplies goods or services to an entity, the Article 14(d) would mark that as beneficial, by the extent to which the remunerations fall short of 
whether such prices should form the benchmark for benefit analysis. The Appellate Body held that under proven circumstances of predominant government role in the market to the effect that private prices are distorted, an investigating authority is justified in relying on out of market prices. ${ }^{911}$ Later, in the $U S-A D$ CVD (China), both the Panel and the AB agreed that similar flexibility also exists under Article 14(b). ${ }^{912}$ There, in the context of loan rates, it was held that when it is established that government intervention in the market has rendered the interest rates unusable as benchmarks, ${ }^{913}$ Article 14 (b) would not preclude establishing a comparable out-of-country benchmark, ${ }^{914}$ as long as it is well approximated. ${ }^{915}$ Such jurisprudence may help establish that in a given situation existing private market reference rates for credits, insurance or guarantees, or absence of such rates therein would call for out-of-market, constructed benchmarks to be used.

While developing a similar argument with respect to the proposed ECA based support measures, one key distinction ought to be made. With respect to LCT incentives, the market situation is different from the exampled disputes. While in the abovementioned situations the government influence distorts a benchmark that could potentially exist, in the current case there may not be any pre-existing benchmark as the clean technology spreading transactions would not otherwise take place at all. Especially in the latter situation, as previously argued, the government intervention is proposed to cure a private capital market failure to allocate an optimal level of resources to facilitate LCT diffusion. In sum, while the proposed promotion of LCT transactions by the

being adequate. It is to be noted that the provision dictates the adequacy of remuneration to be determined 'in relation to' the prevailing market conditions.

911 United States - Final Countervailing Duty Determination with Respect to Certain Softwood Lumber from Canada [2004] Appellate Body Report WT/DS257/AB/R, DSR 2004:II 571 [103.]. The conclusion was arrived at by the Appellate Body based on the finding that with the phrase 'in relation to' in Article 14(d) the drafters did not intend to exclude the possibility of using alternate benchmarks [para 88-89]. This was a conclusion, which according to the AB was supported by the intent and purpose of the SCM agreement [9395]. Surprisingly the $\mathrm{AB}$ analysis began by an agreement with the Panel that provision in question does not call for comparison with a purely free market [87].

912 United States - Countervailing and Anti-Dumping Measures on Certain Products from China [2014] Panel Report WT/DS449/R, DSR 2014:VIII 3175 [10.40-10.45]; United States Countervailing and Anti-Dumping Measures on Certain Products from China [2014] Appellate Body Report WT/DS449/AB/R, DSR 2014:VIII 3027 [489].

913 United States - Countervailing and Anti-Dumping Measures on Certain Products from China (n 912) para 479 .

914 ibid 48o.

915 ibid $482-483$. Such approximation comprises of various factors, including the repayment terms, time of the loan, maturity, size, and currency [paras 475-476, 486]. 
ECA $s$ is indeed a positive intervention in the financial market, it may have an effect of establishing a new benchmark standard, rather than distorting and existing one.

In connection with the above, it can further be argued that the financial market space where the intervention takes place is already distorted, as it does not allocate resources in an optimal fashion. Therefore, any positive intervention to alter such a situation shall not be automatically considered as conferment of benefit to the recipient. Instead, such interventions should only be compared to similar situations. This position can be substantiated drawing support from the $\mathrm{AB}$ decision in the Canada-Renewable Energy dispute. With respect to Article 1, and in context of Article 14(d) of the SCM agreement, one of the questions in that dispute was whether the remuneration provided by the respondent government was 'more than adequate.'916 The Appellate Body clarified that to define the scope of the relevant market in which a benefit is considered to have been conferred, one ought to take into account all available evidence, including supply-side considerations, and government demand preference, if any. ${ }^{917}$ The Appellate Body further mentioned that finding of the appropriate benchmark in the relevant market should not be considered as thwarted by government intervention, more so in situation where the market itself is an outcome of such intervention. ${ }^{918}$ The $\mathrm{AB}$ also proposed that the situations of a new market creation and distortion of an existing one should be distinguished from one another when looking for the potential existence of benefit due to government intervention in any market. ${ }^{919}$ Where a new market is created, the benchmark of benefit ought to be found in that market, or by constructing a proxy for comparison. ${ }^{920}$ It is relevant to recall that in the dispute, an ideal benefit benchmark to measure remuneration provided to the renewable energy suppliers was eventually considered to be one that takes account of the intended government supply-mix and reflects what a market would yield. ${ }^{921}$ The latter or the proxy thereof could be found in administered prices or through price discovery mechanisms. ${ }^{922}$

\footnotetext{
916 Canada - Certain Measures Affecting the Renewable Energy Generation Sector / CanadaMeasures Relating to the Feed-in Tariff Program (n 500) para 5.159-5.161.

917 ibid 5.171-5.178. To note - "The definition of a certain supply-mix by the government cannot in and of itself be considered as conferring a benefit within the meaning of Article 1.1(b)." [Para 5.175].

918 ibid 5.182.

919 ibid 5.188.

920 ibid 5.184, 5.227-5.228.

921 ibid $5.225-5.227$.

922 ibid 5.228.
} 
We see that the position taken by the $\mathrm{AB}$ in the above dispute bolsters the argument that the market of climate technology related export credits is distinguishable from the general financial market due to a given a specific policy prerogative, domestically or internationally. While measuring the benefit benchmark in the appropriate context of Article 14(b) or 14(c) of the ASCM, it should be remembered that those provisions have the similar flexibility like Article 14(d), as mentioned above. Moreover, nothing in the AB elaboration of relevant market identification indicates that it should only be applicable to situations guided by Article 14(d). With respect to assessing the LCT support activities of the ECA s, the relevant market can be seen as that of finance terms offered by the sellers of LCT s and accepted by the buyers. ECA support for such transaction should not in and of itself be considered a subsidy, only because such transactions would not otherwise take place.

Practical benefit of the above argument can be subject to some scepticism at least. First, the ECAs at present do not operate under a climate protection mandate. ${ }^{923}$ Those that promote climate projects, do so due to the unique specialisation of the domestic industries. ${ }^{924}$ So it would be difficult to justify an ECA measure as a climate policy-driven market formation initiative. Second, the new market creation argument will not work in situations where there are private financial entities offering support to clean technology exporters and investors, but doing so at a high rate. The offering of better credit terms by the ECA s in such situations has less chances to avoid being seen as a subsidy. Third, success of the market creation argument can prove to be counterproductive, if there are no checks on the public policy motives considered as an eligible excuse for new market formation. If the argument, as employed in the Canada - Renewable Energy dispute, is allowed to serve any preferred policy intent by the government, it can hypothetically be extended to everywhere, e.g. saving coal jobs, or ensuring affordable access to power through coal power plants etc. As a result, in the absence of further normative limitations, the AB interpretation in that dispute is dangerous to follow. The potential utility of the

923 We highlight the latter part of a paragraph cited earlier. The Appellate Body, while quoting the Panel, holds that ' $[\mathrm{c}]$ onsideration related to [the] externalities will often [...] be the reason why governments intervene to create markets [...]. On this point, we agree with the Panel's statement that, where government intervention that internalizes social costs and benefits is limited to defining the broad parameters of the market, "significant scope will remain for private actors to operate within those parameters on the basis of commercial considerations"'. ibid 5.189.

924 The developed countries still remain the leaders in low-carbon innovation. See Chapter 2 III A at pp. 77-79 above. 
doctrine of Common Concern to limit the scope of this approach, as well as to find alternate benchmarks are discussed later in the chapter. ${ }^{925}$

To conclude, government financial contribution for clean technology export through the supply of credits or guarantees may not as straightforwardly be construed as a subsidy, as it may seem upon first look. There is some opportunity to argue that a clean technology supporting financial measures belong to an exclusive market and therefore should only be compared with a benchmark therein. If not readily available, such a benchmark should be constructed. While this approach may prevent any such financial support from being considered a subsidy per se, it ought to be noted that a detailed, fact-intensive benefit analysis will not always save a measure. Also, making an argument as such requires further opportunity be made available to a dispute settlement Panel to make normative distinctions between policy objectives.

\section{(iii) Incentives Falling outside the ASCM Coverage}

There is nothing in the SCM agreement's definition of subsidies that prevent an investment incentive from falling under its scope. However, no such measure can come under the scrutiny of its rules, because it was not the intent of the drafters to expand the scope of the covered agreements to investment activities. This is clear from the Marrakesh Agreement Establishing the World Trade Organization, as well as the earlier GATT. Article XVI of GATT, which is the predecessor of the ASCM, mentions that the provision comes into play only when a subsidy "operates directly or indirectly to increase exports [...] or reduce imports [...]". ${ }^{226}$ Later, the Marrakesh Agreement articulated the objective of the wTO as to "provide the common institutional framework for the conduct of trade relations among its members [...]".927 In a rare exploration of the impact of home state measures to promote investment, Sauvant and others have noted that often the home country measures (HCM) to promote OFDI and trade-related subsidies are provided by the same agencies. While the latter frequently came under scrutiny at the WTO court, the authors maintain that HCM s are unregulated. ${ }^{928}$

It is also not likely that supports by the multilateral development banks (МDB), or other international financial institutions (IFI) will be considered as a subsidy. Such supports can neither be attributed to a domestic government, nor a public body within the meaning of the term elaborated earlier. The

925 See section III A at pp. 233-234 below.

926 Article XVI(1), General Agreement on Tariffs and Trade ( $\mathrm{n} 426$ ).

927 Article II(1), Marrakesh Agreement Establishing the World Trade Organization (n 226).

928 Box 1, 'HCMs and the WTO's Agreement on Subsidies and Countervailing Measures', Sauvant and others (n 852). 
M D B s work at a supra-national level. Furthermore, only a public body 'within the territories' of a WTO member may fall within the scope of the definition. ${ }^{929}$ It should also be noted that the Panel in the $E C$ - Large Civil Aircraft dispute mentioned that even though services rendered by a multilateral financial institution may conspicuously fall within the terms of the definition, hardly any may be such that can be considered actionable. ${ }^{930}$

Moreover, like the ASCM, which deals with subsidisation with regard to trade in goods, there are no comparable rules regarding trade in services. Although the што members have committed to negotiate on the multilateral disciplines on removing the distortive effects of services subsidisation while taking account of the developing country needs in particular, any substantive rules are yet to emerge. ${ }^{931}$ As a result, it remains possible to supply services related to LCT s, like education, training, engineering and construction, transport, accounting, and financial services to the developing countries in subsidised terms, without drawing a challenge under the current WTO rules.

In sum, there are no obstacles for the developed countries to incentivise the domestic technology holders in making greenfield investments to technology seeking destinations. The same official public assistance measures as proposed in this chapter can trigger and support investment outflows as well. One way would be to provide incentives to the parent firms when they supply better emission reduction technologies to their developing country subsidiaries. Trade and investment promotion supports of any form, when coming from the MDB s, remain outside the ASCM scope as well. Beyond the scope of the proposed measures, supply of climate technology related services to developing countries can also be incentivised without breaking wTO rules.

\section{Export Incentive and Regulation on Prohibited Subsidies}

The structure of the SCM agreement provides one shortcut route to challenge export credit activities. This is by claiming a breach of the illustrative list of prohibited subsidies. The list, appended to the SCM agreement as an annex, is a historic legacy that has been carried over to the wTO rules framework. It was the outcome of the GATT era attempts by the contracting parties to regulate trade distortive subsidies. As a definition of subsidy could not be agreed upon, the best compromise outcome was a list that designated certain circumstances

929 Coppens, 'Disciplines on Export Credit Support for Non-Agricultural Products' (n 895) 362 .

930 European Communities and Certain Member States - Measures Affecting Trade in Large Civil Aircraft (n 898) 7.888.

931 Article Xv, General Agreement on Trade in Services (n 428). 
and thresholds in and beyond which government supports are prohibited. As the SCM agreement inherited the list, it serves as instances of clear cases where a subsidy is contingent on export performance. Items ' $\mathrm{j}$ ' and ' $\mathrm{k}$ ' of the list lay down threshold conditions for government support made through guarantees, insurances, and credits. Therefore, to the extent the level of official direct credit support or pure cover support goes beyond the suggested thresholds therein, a case of per se breach can be made, without even needing to separately establish the existence of subsidisation. ${ }^{932}$

The wording of the paragraph ' $\mathrm{k}$ ' of the illustrative list also contains a rare exception, one that saves certain export credit measures when those are in line with the relevant 'interest rate provisions' of the OECD arrangement. Since the lapse of the non-actionable subsidies, this provision, known as the 'safe-haven', is the only exception mechanism applicable with respect to export credits.

That apart, government promotion of clean technology through the ECA s are amenable to be challenged as a prohibited export subsidy. As already mentioned, Article 3.1(a) of the Subsidies Agreement prohibits subsidies that are contingent upon export performance, either in law or in fact. Although it intuitively appears that an export credit would be found to be contingent on exportation, we will see that a lot depends on the design and actual operation of the measure as well as the specific characteristics in each instance.

\section{Per Se Prohibition under the Illustrative List}

The common element in both the list provisions is that, characteristic to the other illustrative list items, a prohibition of support provided at a net cost to the government. This, except for explicit exceptions, is the main purpose of the list - i.e. establishment of certain clear cases of prohibited subsidies. The list is also unique as all the cases therein are examples of costs incurred by the government, which is a standard that was eventually avoided in the later agreed definition of 'subsidy' incorporated the SCM agreement. Here we take a closer look at the two relevant list provisions and their implication for LCT support.

a) Item 'j': Pure Cover Supports

Item ' $\mathrm{j}$ ' prevents the following-

The provision by governments (or special institutions controlled by governments) of export credit guarantee or insurance programmes, of insurance

932 Korea - Measures Affecting Trade in Commercial Vessels [2005] Panel Report WT/DS273/ R, DSR 2005:VII 2749 [7.204]; Canada - Export Credits and Loan Guarantees for Regional Aircraft (n 899) para 7.395. 
or guarantee programmes against increases in the cost of exported products or of exchange risk programmes, at premium rates which are inadequate to cover the long-term operating costs and losses of the programmes.

A plain reading of the text would correctly suggest that the prohibition is on incurring net costs in the long run with respect to a pure cover support programme. Breach of this provision is only established by evaluating the longterm performance of the program in its entirety, and when proved, the whole program will be considered prohibited.

The immediate question that would arise is whether all forms of insurances and guarantees to facilitate LCT related commercial transactions will attract the involvement of the item ' $\mathrm{j}$ ', which upon reading appears to be of limited scope. As the text shows, operation of the paragraph extends to programmes providing security against cost increases of exported products and exchange risks. While none of the dispute decisions so far have elucidated what this entails, it is possible to envisage that not all forms of risk supports extended by an ECA with respect to LCT transactions relate to protection against price increase or exchange rate risks. For example, a seller may be prompted to disengage from a potential transaction due to political, or financial risks being involved, or simply due to lack of information, irrespective of the price performance of the export or the prevalent currency exchange rates. Risk sharing programs to assist a seller in such situations seemingly will not come under the coverage of the item ' $\mathrm{j}$ '. These can therefore only be dealt with under the general rule on export subsidy under Article 3.1(a) of the agreement.

The nature of the evidence required to establish a breach of the paragraph 'j' may further make it difficult for a complainant to challenge an LCT support program. So far, only in the US - Upland Cotton dispute, the Panel was provided with an opportunity to explore that question of evidentiary requirement. The Panel expounded therein that it was not the precise amount of a premium, but the adequacy of it to cover the long-term costs of the program was subject to assessment under paragraph ' $\mathrm{j}$ ' ${ }^{933}$ To that effect, the Panel's extensive analysis of the respondent's export credit programmes comprised of an assessment of the past performance whether the programmes were run at net cost or not, also of the relevant elements of the programmes' structure, design, and operation. ${ }^{934}$ The approach was later endorsed by the $\mathrm{AB} .{ }^{935}$ In that dispute, data

\footnotetext{
933 United States - Subsidies on Upland Cotton [2005] Panel Report WT/DS267/R, DSR 2005:II 299 [7.823-7.825].

934 ibid 7.841.

935 United States - Subsidies on Upland Cotton (n 9o6) paras 664-674.
} 
ranging for a period of 10 years (1992-2002) was considered by the Panel. Given the confidential nature of the export credit support programmes, producing such detailed data for the respondent is not bereft of substantial complexity for the complainant. In the absence of appropriate measures to protect business confidential information, the respondent may also refuse to supply the data necessary to prove the case..$^{936}$

With special regard to climate change related transactions, yet another question could be whether, or how the financial benefit of avoided emission in the long-run would be factored in measuring the operating costs and losses of a government insurance or guarantee program. If the government program to support clean technology transactions is guided by the motive to resolve a common concern, then the avoided emission is undoubtedly a benefit the government seeks to generate with the support. It makes reasonable sense if the computation of the long-term cost of a program also takes account of the benefit generated by avoiding costly emissions. One problem, however, is that such benefit would probably need to somehow accrue to the provider to be taken into account. These are questions that remain unresolved.

It should also be noted that the OECD arrangement, while providing for guidelines on credit risk premium, obliges the participants to pay at least the minimum rates (MPRs). What is of interest is that Article 23 of the arrangement holds that the "premium rates [...] shall not be inadequate to cover longterm operating costs and losses". This borrowed language from paragraph ' $\mathrm{j}$ ' raises the question of whether the OECD suggested MPR s would per se be probative of the absence of net cost support by the credit supplier. While the construction of the MPR S may factually make sure that a pure cover support program by the ECA is not run at net cost, from a legal point of view, compliance with the MPR may not automatically shield from the finding of paragraph 'j' breach, for reasons mentioned in later paragraphs. ${ }^{937}$ Such compliance may nonetheless be of factual support when the long-run performance of the program will be assessed.

b) Item ' $k$ ', First Paragraph: Direct Credit Support

First paragraph of the item ' $\mathrm{k}$ ' prevents the following-

The grant by governments [...] of export credits at rates below those which they actually have to pay for the funds so employed [...], or the

936 Canada - Measures Affecting the Export of Civilian Aircraft (n 9o5) para 9.175-9.177, 9.188-9.189.

937 See Chapter 5 II C (iii) at pp. 228-229. 
payment by them of all or part of the costs incurred by exporters or financial institutions in obtaining credits, in so far as they are used to secure a material advantage in the field of export credit terms.

The provision deals with direct supports, in the form of direct credits or interest rate supports, either fully or in part. What is prohibited are transactions that result in a net cost to the government. This is also the point of similarity of the current provision when compared to paragraph ' $j$ '. However, the difference lies in the fact that while the previous provision assesses the net cost in the long run, no similar temporal bound exists in the current provision. Therefore, a complainant can challenge individual export credit transactions as being in breach of the item ' $\mathrm{k}$ ' of the illustrative list.

The general issue, equally persisting regarding the LCT related transactions, is that of determining 'material advantage' as prohibited in the above provision. This remains open for interpretation. In one instance, the Appellate Body held that a rate of interest below the CIRR could raise a rebuttable presumption that advantage gained has been material. ${ }^{938}$ This can serve only an illustrative purpose and not more, as the rules of treaty interpretation would not endorse equating the scope of the meaning of 'material advantage' as that going above the CIRR. In absence of an express mention in the text of the provision, the OECD arrangement may only have very little contextual relevance for interpretative purposes.

Arguably, a finding that a technology export promoting measure does not constitute material advantage provided to the producer per se, does not make the respondent any safe. Because a complainant, failing to establish a breach of the illustrative list, can nevertheless challenge the subsidy as violating Article 3.1(a) provision. It has however been claimed that the illustrative list provision can be flipped and used as a defence. As the paragraph portrays export subsidy as net cost export credits provided to secure material advantage, Brazil, as a respondent argued in a dispute that if, on the contrary, it is proven that the measure is not taken to secure material advantage, it should be sufficient to conclude that it is not prohibited at all. ${ }^{939}$ We look at this a contrario claim below.

938 Brazil - Export Financing Programme for Aircraft - Recourse by Canada to Article 21.5 of the DSU [2000] Appellate Body Report wT/DS46/AB/RW, DSR 2000:VIII 4067 [64, 67]; Coppens, 'Disciplines on Export Credit Support for Non-Agricultural Products' (n 895) 371-372.

939 The basis of the argument lies in footnote 5 of the sсм agreement which provides that - " $[\mathrm{m}]$ easures referred to in Annex I as not constituting export subsidies shall not 


$$
\begin{aligned}
& \text { Interpreting A Contrario: "So Far as [...] to Secure a Material } \\
& \text { Advantage" }
\end{aligned}
$$

The a contrario argument is not an example of logical coherence. We recall that the first paragraph of item ' $\mathrm{k}$ ' provides one illustration of prohibited export credit support, i.e. when provided at a 'net cost' to the government and resulting in 'material advantage' to the recipient. Disproving either, or both of these requirements can only mean that the measure is not prohibited within the illustrated scenario of item ' $\mathrm{k}$ '. Falling out of the coverage of this one specific scenario does not logically imply that the measure is absolved of any possible prohibited characteristics. The first paragraph does not lay down anything on situations that "do not constitute export subsidy" as laid down in footnote 5.940 Therefore this line of argument is unmeritorious.

In the Brazil - Aircraft 21.5 dispute, the Panel categorically rejected the $a$ contrario argument for the first time. ${ }^{941}$ Noting that the footnote 5 extends to only those provisions that affirmatively regard a transaction as not prohibited, the panel indicated that the first paragraph of item ' $\mathrm{k}$ ' is not worded as an affirmative exception. ${ }^{942}$ Treating it as such would have taken away the special meaning of the distinctive drafting of the affirmative exceptions in the illustrative list (e.g. safe-haven clause in the second paragraph). The panel also highlighted that such a reading would eventually run counter to the interests of the developing countries, as it would be comparatively easier for a developed country to subsidise exporters. ${ }^{943}$ It was also noted that attempts at that time of reforming the SCM agreement proposed modified language for footnote 5 that does away with the opportunity of making such an argument. ${ }^{944}$

However, this issue lingers because the Appellate Body did not follow suit in categorically rejecting the $a$ contrario argument. The AB did not endorse it either. While addressing the respondent's appeal in the above dispute, the AB decided that Brazil failed to discharge the burden of establishing the benchmark

be prohibited under this or any other provision of this Agreement" [emphasis supplied]. Brazil maintained this position throughout the aircraft disputes.

940 Ibid.

941 Brazil-Export Financing Programme for Aircraft-Recourse by Canada to Article 21.5 of the DSU [2000] Panel Report WT/DS46/RW, DSR 2000:IX 4093 10-23; The conclusions were confirmed by the panel in the second compliance dispute as well. See Brazil - Export Financing Programme for Aircraft - Second Recourse by Canada to Article 21.5 of the DSU ( $\mathrm{n}$ 9о4) 61-63.

942 Brazil - Export Financing Programme for Aircraft - Recourse by Canada to Article 21.5 of the DSU (n 941) para 6.36-6.37.

943 ibid 6.57-6.59.

944 ibid 6.39-6.41. 
(other than the CIRR) against which material advantage is to be measured. ${ }^{945}$ This precluded the $\mathrm{AB}$ from addressing the argument that no material advantage was provided. However, the $\mathrm{AB}$ mentioned that if Brazil would have discharged the burden of proof, it could have been found that the measure was "justified under item (k) of the Illustrative List". ${ }^{946}$ As a result, though logically unsound, there remains a sliver of possibility that the a contrario argument may be entertained in the future.

Even allowing an a contrario reading would not be particularly beneficial to the LCT export incentives. If it develops as a carve-out, it would be a general one. Nothing would prevent the members from using the defence for climate defeating purposes.

(iii) The Utility of Compliance with the OECD Arrangement The safe-haven, found in the second paragraph of item ' $k$ ' of the illustrative list, provides that "if a member is a party to [the OECD arrangement], or if in practice a member applies the interest rates provisions of the relevant undertaking, an export credit practice which conforms with those provisions shall not be considered an export subsidy prohibited by this Agreement". Once again, the wording is reminiscent of so far back a past that at present it gives rise to intractable ambiguities, as well as legitimacy challenges potentially affecting LCT related official support as much as others.

The plain reading of the provision above suggests that there are two points of entry to the affirmative exception of the safe-haven. One is by actual participation in the OECD arrangement, and another by applying in practice the interest rate provisions of the prevailing version at the time. In both cases, the outcome is that the member's export credit practice is safe from being prohibited as long as there is compliance with the interest rate provisions. Therefore, it is a hypothetical possibility that some of the LCT related official support measures will fall within the coverage of the safe-haven.

From a legal point of view, the scope of the carve-out depends on how one understands the term 'export credit practice' in the provision reproduced above. It was initially held that the meaning should in no way be limited to specific forms of transactions. ${ }^{947}$ In that sense, the safe-haven may save both direct

945 Brazil - Export Financing Programme for Aircraft-Recourse by Canada to Article 21.5 of the DSU (n 938) 23-25.

946 ibid 8o. [emphasis supplied].

947 Canada - Measures Affecting the Export of Civilian Aircraft (n 905) para 5.81; Brazil Export Financing Programme for Aircraft - Second Recourse by Canada to Article 21.5 of the DSU (n 904) para 5.65-5.66. 
credit supports (direct finance, re-finance, and interest rate support) and pure cover supports (credit guarantees and insurances). However, according to later Panels, the additional requirement of applying the 'interest rate provisions' therein would limit the scope of the safe-haven only to those support measures regarding which the interest rates play a role. Taking the interest rates to be the CIRR, Panels narrowed down the scope of the safe-haven to one specific type of support, i.e. direct export credits on fixed interest rates. ${ }^{948}$ It conforms with the provisions of the arrangement, as the CIRR is applicable therein only with respect to official financing supports advanced at fixed rates, ${ }^{949}$ with a repayment term of two years or more. ${ }^{950}$

While one may nevertheless argue for a wider interpretation of the term 'interest rate provisions', so as to comprise also guidelines on the floating rate credits, guarantees, and insurances, this would depart not only from the literal understanding of the safe-haven, but also the common intent animated in the related illustrative list provisions. At the time of drawing up the list, the concepts of minimum premium rates (MPR s) for risks and floating rate loans were not existing as modes of official support. The version of the OECD arrangement prevailing at that time did not contain any such provisions as well. In those early days, most of the export credit practice comprised of fixed-rate credits. Moreover, the subject-matter term to be interpreted here, i.e. 'interest rate provision', is of particularly technical in nature, which is limitative of a possible evolutionary understanding. Nevertheless, there are indeed instances in trade law jurisprudence, where underlying common intent of the covered agreements has been construed in ways not completely foreseen. ${ }^{951}$ Providing a wider scope of meaning to the term 'interest rate provision' may serve to bring the floating rate supports within the safe-haven coverage. But bringing the MPR s within its folds would indeed be overstretching.

948 Coppens, 'Disciplines on Export Credit Support for Non-Agricultural Products' (n 895) 380; Canada - Measures Affecting the Export of Civilian Aircraft - Recourse by Brazil to Article 21.5 of the DSU [2000] Panel Report WT/DS70/RW, DSR 2000:IX 4315 [5.93-5.106]; Brazil - Export Financing Programme for Aircraft - Second Recourse by Canada to Article 21.5 of the DSU (n 904) para 5.102.

949 Article 19, OECD, 'arrangement on Officially Supported Export Credits' (n 865).

950 Article 5, ibid.

951 For example, in the United States - Gambling and Betting Services (DS 285), it was determined that commitments relating to trade in services scheduled by a Member would also cover instances of supply over the internet. While well-reasoned, this decision cannot be said to be an outcome commonly envisaged by the Members at the time of negotiating the GATS provisions. For a detailed review, see Sascha Wunsch-Vincent, 'The Internet, Cross-Border Trade in Services, and the GATS: Lessons from US-Gambling' (2006) 5 World Trade Review 319. 
Compliance with the interest rate provisions may not provide any special advantage to boosting LCT transactions. As mentioned before, the ECAs themselves are primarily motivated to promote export by complementing the private financial flows. Therefore, any general saving of official support measures by the ECA $s$ is going to be of use for all forms of economic activities, which may end up increasing rather than lowering global emissions. Also, required compliance with the CIRR in the OECD arrangement is only useful to peg the lending rates against the currency of the participants and to prevent a downward competition in that regard among the dominant players. ${ }^{952}$ Such prevention may not even be a good idea, as freer competition in export credit terms, especially when offered to the cash poor developing country buyers, may see more public financial resources being invested in facilitating clean technology transactions. While it is not impossible to introduce more flexibility regarding interest rates for LCT related transactions in the arrangement, no such effort is forthcoming. Nor is there any step on expanding the subject-matter scope of the climate mitigation understanding in the arrangement.

Apart from the safe-haven provision, the overall influence sought to be exercised by the participants to the arrangement upon the SCM agreement provision is not beyond criticism. As already mentioned, the compliance with the arrangement provision has already been provided probative value by the $A B$ with respect to legal issues beyond the safe-haven clause. Furthermore, the arrangement language keeps evolving in a fashion that seeks to influence the understanding of other illustrative list provisions, especially the item ' $\mathrm{j}$ ' therein. Article 23 of the arrangement currently provides that " $[\mathrm{t}]$ he premium rates charged by the Participants shall [...] not be inadequate to cover long-term operating costs and losses". This opens the possibility that in later disputes, compliance with the MPR $\mathrm{s}$ will be taken as presumptive of abidance with the item ' $\mathrm{j}$ ' requirement. Similarly, with regard to the provision on matching, ${ }^{953}$ the wording suggests that a participant would not be found to be in contravention of the arrangement rules when matching interest rates below the CIR R by other participant or non-participant. ${ }^{954}$ Therefore, a case of matching can still

952 Article 20, Chapter II, OECD, 'arrangement on Officially Supported Export Credits' (n 865). The (CIRR) are calculated for currencies of the participating members upon request, based on the rate of return on respective bonds.

953 For 'matching', see Box 4 at p. 205 above.

954 Article 18, OECD, 'arrangement on Officially Supported Export Credits' (n 865). It holds that 'Financial terms and conditions provided in accordance with this Article are considered to be in conformity with the provisions of Chapters I, II [...]'. Chapter II contains the interest rate provisions of the arrangement. 
be found to be consistent with the interest rate provisions of the arrangement while effectively going below the CIRR rates. These de facto influences that can be exercised through the arrangement provision, raises a legitimacy question, as the participants to the OECD arrangement is only a handful of high-income developed countries. We will revert to this issue while discussing the possible avenues for reforming the SCM agreement in light of the Common Concern doctrine.

\section{The De Facto or De Jure Export Contingency}

Subsidies that are contingent on export performance are prohibited under the ASCM. This includes both de jure, and de facto contingencies. This raises the question of whether any official export credit support, except for those in compliance with the OECD interests rates, can be saved if found to constitute a subsidy. The answer depends on the meaning of export contingency. A subsidy is contingent on export performance when boosting export is a condition to the grant. The distinction between de jure and de facto export contingency is that in the former case the conditionality can be read from the law explicitly or by implication, ${ }^{955}$ whereas in the latter case it is a fact-driven exercise. Export finance instruments, when considerable as a subsidy, may clearly be de jure export subsidy as it only focuses on export transactions. Also, with contextual support drawn from the illustrative list, it would be so confirmed.

Even if the ECA supports are not considered de jure export contingent, they cannot avoid being taken as de facto contingent. The de facto export contingency is a well-tuned standard, where the ultimate goal is to determine whether a subsidy under consideration changes the undistorted market performance of the recipient in a fashion that is relatively export boosting. ${ }^{956}$ This investigation takes account of the design, structure, and operation of the measure in question, as well as the relevant surrounding features. In the $E c$ - Large Civil Aircraft dispute, the $\mathrm{AB}$ mentions that one way of finding de facto contingency would be comparing the ratio between anticipated export and domestic production after the subsidy and the same ratio before such support. ${ }^{957}$ It has been emphasised that the "total configuration of facts constituting and surrounding the grant" should be taken into account. The mere knowledge that

955 European Communities and Certain Member States - Measures Affecting Trade in Large Civil Aircraft (n 815) para 1038. The report in turn cited a former Ав report, CanadaMeasures Affecting the Export of Civilian Aircraft (n 905) para 167.

956 European Communities and Certain Member States - Measures Affecting Trade in Large Civil Aircraft (n 816) para 1045.

957 ibid 1047, 1056 . 
the recipient's business is export-oriented in nature does not prove export contingency in itself. 958 Policy intent, however benevolent, would not save a financial support from being seen as de facto export contingent. Altogether, it would appear that measures exclusively promoting export transactions of LCT s such as the one proposed in this chapter would be found as de facto contingent upon export performance.

The brief discussion above serves to show the difficulty in saving an LCT enhancing official export credit measure from being considered as a prohibited subsidy. There are certain design features that may provide little shelter making a finding of export contingency somewhat difficult. For example, if a measure that boosts domestic, as well as export transactions at similar rates would be difficult to be found as illegal. The proposed measure would require further adaptation to make use of this shelter.

\section{Other Challenges to the Export Promotion Incentives}

(i) Specificity

Apart from the prohibited category, subsidies can only be challenged when those are specific. Finding a subsidy as specific can eventually be a factual determination exercise unless the support is legally constrained to specific entities, enterprises, or industries. The factual consideration in this regard includes the characteristics of the recipient enterprises, the manner of the grant by the authorities, as well as the time period of the grant etc. The specificity requirement highlights that the design of the incentives would play a role. Open-ended, transparent, and industry-wide availability of such support would help the finding of non-specificity. For the same reasons, it may as well be difficult to find official export promotion supports as specific, as these programs tend not to distinguish between industries, or sectors. The same applies to LCT diffusion support as well. Any official support measure should be made wide enough so that relevant mitigation technologies in any part of the destination country's economy can come under the coverage.

Actionability

Even though a technology export credit is saved by the safe-haven provision, it is not saved from challenges under other parts of the SCM agreement when found to be specific in nature. This is despite the mention in the Agreement that measures the illustrative list declares as not constituting prohibited subsidy shall not be so construed under any other provisions. ${ }^{959}$ The Appellate

$95^{8}$ Canada-Measures Affecting the Export of Civilian Aircraft (n 905) 167-173.

959 Footnote 5, Agreement on Subsidies and Countervailing Measures (n 434). 
Body chose to read the relevant language narrowly, construing that the expression only related to the determination of the prohibited nature of the subsidy and not determination of the actionability altogether. ${ }^{960}$ The reading opens the possibility that even the arrangement compliant official export credit supports can be challenged multilaterally as an actionable subsidy or unilaterally countervailed.

Earlier we have assumed that it would be less plausible that the countries gaining access to new technologies as a result of official support, would launch a countervailing duty investigation or challenge such measures in dispute on account of adverse effects to domestic industries. Even in absence of such challenge, it is probable that third parties, e.g. WTо members having a competing industry in the technology sector in question may bring a dispute against the member extending the export credit on account of 'serious prejudice'.961 According to Article 6.3, a member can be seriously prejudiced if, inter alia, subsidies displace or impede its exports in a third country market; or if the subsidy results in significant price undercutting. In cases where export credit support goes to a foreign sector facing competing export interests (e.g. export of solar panels) from elsewhere, it can plausibly draw complaints from the competitors.

The foregoing section made a detailed explanation showing that the extent to which official support for LCT exports come under the SCM agreement, they could be challenged in disputes, except for the supports provided at fixed interests rates in line with the OECD arrangement. Looking forward, two avenues appear. One is to avoid support options that draw challenge under the SCM agreement. This means support through the non-governmental institutions, as well as concentrating incentives to domestic companies for OFDI activities involving clean technologies. Another avenue is to look at whether the doctrine of Common Concern supplies any suggestion towards saving the export support measures within the ASCM scope. This section further elaborates upon the second avenue. It explores the implications of the doctrine with respect to

96o United States - Tax Treatment for 'Foreign Sales Corporations' [200o] Appellate Body Report WT/DS108/AB/R, DSR 2000:III 1619 [93]; Coppens, 'Disciplines on Export Credit Support for Non-Agricultural Products' (n 895) 387.

961 Article 5(c) read with Article 6.3, Agreement on Subsidies and Countervailing Measures (n 434). 
the status quo, and also takes a close look at the possibilities of moving forward in circumstances where the current paradigm provides no solution. While the former calls for finding a favourable reading of the existing rules, the latter would require examining the opportunities for reform.

\section{A As an Aid to Interpretation}

The doctrine of Common Concern can be of aid to further structure the reconciling position taken by the $\mathrm{AB}$ with respect to measuring benefit in the context of subsidy determination. We recall that the Ав decision in the Canada - Renewable Energy endorsed the possibility that the governments may, driven by policy reasons, create heretofore non-existent markets. ${ }^{962}$ It has been explained earlier that although policy considerations found a way into the determination of a benefit benchmark, so far no normative criterion exists to evaluate the preference of one policy goal over another. Without any limits, such an approach can fall prey to arbitrary designations of policy goals, resulting in unabated subsidisation. ${ }^{963}$ Instead of being all-out critical of the Ав position like most scholars, it is submitted that if public policy motivation to intervene in the existing market is given overriding precedence only in cases marked by the necessity to address otherwise intractable market failures, a reasonable distinction could be created between favourable government interventions others. The Common Concern doctrine will be helpful to that effect.

Within a recognised frame of Common Concern, as laid out in Chapter 3 , official support measures for higher exports of LCT s would be seen in a favourable light. In the context of the proposed narrative therein, resolving the failure of private financial markets to channel adequate resources for transactions favouring LCT s is an obligation that must be discharged through complementary public support. Common Concern, therefore, strengthens the policy position that governments can and should take measures to boost technology supply for internalising emission externalities across borders, by enabling realisation of new export transactions that would not take place under current market terms. Such new transactions, made possible through official technology support should not be deemed as subsidies per se. Rather, whether

962 See p. 218 above.

963 Luca Rubini, 'ASCM Disciplines and Recent WTO Case Law Devlopments: What Space for "Green" Subsidies?' in Thomas Cottier and Ilaria Espa (eds), International Trade in Sustainable Electricity: Regulatory Challenges in International Economic Law (Cambridge University Press 2017) 330-331; Luca Rubini, “"The Wide and the Narrow Gate": Benchmarking in the SCM agreement after the Canada-Renewable Energy/FIT Ruling' (2015) 14 World Trade Review 211, 222-223. 
benefit has been conferred in such a situation would call for construction of a benchmark taking into account all the relevant factors. While the nature of relevant information may vary from case to case, some recurrent factor to take under consideration can include the necessity of the transaction evidenced by its contribution in resolving a Common Concern, the risk profile of the technology recipient country and firm, cost information of the exporter etc. One concrete approach can be to take the relevant interest or premium rate as suggested by the OECD arrangement, and making further adjustment thereupon. ${ }^{964}$ Ultimately, as long as a transaction is necessary to respond to a Common Concern, official support thereof should be considered beneficial only if it results in a more than a reasonable profit to the recipient. The utility of the Common Concern of Humankind doctrine would lie in its assistance to highlight an existing market failure regarding LCT finances and also to construct an appropriate alternative benchmark for analysis.

The doctrine of Common Concern may also be useful to ease the standard to be met under the illustrative list provisions. For example, with respect to supports provided in the form of insurances and guarantees, the net long term operating costs and losses of the program can be determined by setting the accumulated costs against the benefit accrued in the form of avoided emissions due to the transaction. This will justify extending supports at lower rates of premiums compared to transactions involving polluting technologies.

Although interpretative assistance from the doctrine of Common Concern may reduce the chances of an official support measure with climate action motivation to be considered outright as a subsidy, it would not work as surely as if it were an exception clause. The possibility of challenging the official support measures for clean technologies as prohibited or distortive would nonetheless remain. The key challenge is that, as the next section explains, the formal legal language endorsing the need for policy-guided intervention using subsidies does not exist anymore in the SCM agreement. In this respect, one option is to expand the application of the GATT Article $\mathrm{XX}$ to the ASCM. Scholarly opinions vary from sceptic ${ }^{965}$ to cautious ${ }^{966}$ and

964 We note that the CIR R or the MPR are determinant of cost to the government. Adjustments, as mentioned above would be further warranted to ensure that a dispute settlement panel can decide on the conferment of benefit to the recipient.

965 Condon, 'Disciplining Clean Energy Subsidies to Speed the Transition to a Low-Carbon World' (n 882) 685-69o.

966 Bradly J Condon, 'Climate Change and Unresolved Issues in WTO Law' (2009) 12 Journal of International Economic Law 895, 903-906; Espa and Marín Durán (n 882) 23-27. The authors in the latter paper share the view that even though Art. Xx scope is extended to the ASCM, it would not be of much practical use. 
enthusiastic ${ }^{967}$ on the viability of any such interpretation of the relevant texts. The optimistic account is based on the role of GATT as the umbrella agreement in the Annex 1A of the Marrakesh Agreement, to which list the ASCM also finds itself. Furthermore, there is an express reference to GATT in Article 32.1 of the SCM agreement - readable as allowing the exception provision to be extended to the latter. ${ }^{968}$ Not only such an extension requires an interpretative leap, made even more difficult due to the changing global politics surrounding the WTO, overall implication of such extension is unpredictable. ${ }^{969}$ Such an approach would also disregard the fact that the SCM agreement initially had a limited escape clause, i.e. Article 8 on non-actionable subsidies, which the members have allowed to lapse along with parts of the Article 6 of the agreement. Arguing that GATT exceptions were always available to the SCM agreement makes efforts by the contracting parties in entering into such delicate balances to a nullity.

\section{B As a Guide for Reform}

Before going further into discussion of the needed reforms of the SCM agreement, we ought to recall that the absence of regulatory reform does not block all the options of supporting cross-border supply of LCTs. There are significant avenues that remain outside the scope of the ASCM, which can be immediately deployed. The doctrine of Common Concern of Humankind would demand that those avenues are explored to the best extent possible.

Discussion in this chapter has revealed that the language of the ASсм is unforgiving to the proposed incentive measures, irrespective of how leniently one tries to read its provisions. Thereupon, it is reasonable to conclude that while subsidies remain a key enabler for clean technology diffusion, it contradicts the predominant neoliberal institutional bent and hence generally rejected. ${ }^{970}$ This leads to arguably the only viable long-term option, ${ }^{971}$ i.e. redrafting the necessary parts of the agreement to legitimise Common Concern

967 Rubini, 'Ain't Wastin' Time No More' (n 882) 559-570.

968 ibid $562-566$. The analysis is based on the Appellate Body decisions in China - Periodicals (DS31) and China - Raw Materials (DS394, DS395 \& DS 398).

969 ibid 570; Condon, 'Disciplining Clean Energy Subsidies to Speed the Transition to a LowCarbon World' (n 882) 686, 69o; Espa and Marín Durán (n 882) 26-27.

970 Daniel Puig, James Arthur Haselip and Fatemeh Bakhtiari, 'The Mismatch between the In-Country Determinants of Technology Transfer, and the Scope of Technology Transfer Initiatives under the United Nations Framework Convention on Climate Change' (2018) 18 International Environmental Agreements: Politics, Law and Economics 659, 666.

971 Rubini, 'ASCM Disciplines and Recent WTO Case Law Devlopments: What Space for "Green" Subsidies?' (n 963) 331-333. 
motivated incentives. The goal would be to introduce a carve-out in the SCM agreement that has well-articulated ends for the promotion of which subsidies will be allowed, and also which are equally useful for both developed and developing countries. This case for legitimising strong policy imperative backed subsidies in general, and official export credit practices in particular, can lead to either calling for the reinstatement of non-actionable subsidies provision (Article 8) in the agreement or proposing an entirely new formulation. The latter is a better option to pursue because not only is the textual formulation of Article 8 dated and focused more upon developed country interests, ${ }^{972}$ but actual revival of the provision would still not save the official export credit supports that are currently prohibited. ${ }^{973}$

As far as incentives promoting export of clean technologies are concerned, those that are transparent, bear a clear potential to address a Common Concern, and consented to by the developing country recipient should be exempted from being found as prohibited or distortive under the SCM agreement. A balance must be struck between allowing climate technology-related export incentives and preventing unnecessary disruption in the world market. Inclusion of a necessity test is the time-tested way to attain that balance. The structure of the GATT general exception clause can serve as a guide to the design of a new carve-out. Within this framework, specific exemptions, e.g. trade financing across the renewable energy value chains to promote climate mitigation and technology transfer, can also be included.

To reiterate, first and foremost, the policy objective must be broadly in line with the goal of sustainable development and within that paradigm, may contribute to a Common Concern of humankind. Second, a form of necessity test must be included. Trade distortion resulted from an export incentive should be balanced with the level of its contribution in addressing a concern. The necessity test should also take into account inter alia, the appropriateness of the technology in question, and the manifested technology need of the recipient (e.g. the technology needs assessments done under the climate framework). Third, resorting to the legitimate exception should only be available as long as such incentives are provided in a fair and transparent manner.

972 For different perspectives on reforming Article 8, see, Charnovitz, 'Green Subsidies and the WTO' (n 882) 6o-69; Sadeq Z Bigdeli, 'Resurrecting the Dead-The Expired NonActionable Subsidies and the Lingering Question of Green Space' (2011) 8 Manchester J. Int'l Econ. L. 2; Rubini, 'Ain't Wastin' Time No More' (n 882) 570-576.

973 Article 8 was targeted only to save actionable subsidies (Part III of the SCM agreement) from litigation challenges and unilateral countervailing measures (Part IV). 
Keeping in mind that multilateral negotiation would be lengthy and complex, if possible at all, an easier yet effective path to follow would be to expand the scope of the safe-haven to all forms of official support measures. One way of achieving this end is to change the safe-haven language to include pure cover supports, as well as those provided at floating rates, or in a hybrid manner. In addition, the coverage of the special rules in the OECD arrangement on official support for climate project should be expanded to include all LCT transactions, and the relevant rates relaxed as long as those transactions bring a clear and direct technology diffusion benefit. As highlighted earlier, influencing the outcome of the WTO rules by modifying OECD rules would suffer from an acute democratic deficit. Alternatively, the key regulations on official support, along with flexible rules for Common Concern guided support measures can be annexed to the SCM agreement and then linked to the safe-haven provision in the illustrative list. A requirement of reporting the terms and amount of support provided can further ensure transparency.

Until any of the above reform efforts are concluded, a periodically renewed peace clause can ensure that clean technology promoting supports are not challenged in disputes.

\section{Cooperation and Homework Avenues}

Once again, homework and cooperation remain at the heart of the success of a Common Concern inspired regulatory framework. As mentioned before, the range of official financial support to LCT flow would be fruitful in an enabling policy environment and in the absence of counterproductive subsidies. These issues are better tackled in a cooperative framework. Within the cooperation narrative outlined in Chapter 3, the key task within the wTо is to create wellcalibrated and specifically focused policy spaces that can legitimise ECA-led supports for LCT exports. The foregoing sections have already addressed the details in that regard. Outside the WTO, the cooperation at the OECD to expand the scope of special rules on climate mitigation projects to comprehensively cover LCT s, as well as relaxing the applicable interest rate provisions upon the same is of immediate special importance.

At the domestic level, the members engaging in official export credit supports must renew the mandate of the export credit agencies (ECAs) to promote LCT exports, especially to destinations not served, or only sparsely served by the private financial markets. While more resources ought to be dedicated to emission-reducing activities, the same should be channelled away from polluting activities, e.g. coal power plants.

Cooperation is not only important to promote official support for LCT exports and investments, but it is also indispensable for the removal of other 
distorting subsidies from the market. The што in general or the Sсм agreement, in particular, cannot provide the basis to tackle all the relevant issues. A framework cooperation agreement in the climate regime should highlight the importance of the activities and assign the roles and responsibilities at different levels, as well as other regimes. The wTO can indeed complement the efforts to incentivise clean technology exports by easing the present constraints along the lines suggested in the previous sections. For example, access to special rates for clean technology export finance can be made conditional upon supplying evidence by a member's adequate action in rationalising domestic fossil fuel subsidies. Bilateral and plurilateral commitments to reduce fossil fuel subsidies also remain feasible. Bilateral agreements between providers and recipients of official support can also avoid in part subsequent challenges of such measures at the wTO.

\section{Conclusion}

This chapter presented an analysis of the opportunities and challenges regarding official support of exports and investments involving LCT s. In specific terms, it dealt with the obstacles posed by the wTO subsidies agreement in this respect. Furthermore, it discussed the potential contributions by the doctrine of Common Concern in tackling the obstacles.

The што and the Sсм agreement therein are attracted with respect to a portion of export credits and guarantees. Activities of the private, as well as international financial institutions, fall outside the scope of the rules as long as there are no government influences therein. Moreover, outward investment promotion activities, though taking the same form of those promoting exports, fall outside the Wто purview. While this is promising for the promotion of green investment, there is no safeguard preventing these opportunities from being exploited to expand climate polluting activities.

Although the SCM agreement would apply to export credits and guarantees for low-carbon technologies, in the light of evolving jurisprudence it can be argued that not all supports will be considered a subsidy. Especially with the support of the Common Concern framework, it can be maintained that the governments can and must undertake these kinds of supports for clean technology export. Only because private markets do not find such transactions profitable, would not mean that complementary government supports are beneficial, and hence considerable as subsidies perse.

When considered as a subsidy, there is little in the ASCM that can shelter the proposed measures from being considered as prohibited. Only the direct 
export credits provided at a fixed rate and compliant with the OECD arrangement rules are saved from being challenged as illegal. With the help of the doctrine of Common Concern, a facilitative reading of the agreement would be possible. But at the end of the day, it would not save the measures from all possible challenges. To attain the latter outcome, the ideal option would be negotiating a new carve-out clause in the SCM agreement. The Common Concern doctrine can guide that effort. Until such reforms are successfully concluded, a periodically renewable peace clause can ensure that legal challenges do not prevent the members from promoting LCT s through official supports.

The doctrine of Common Concern would again highlight the need for adequate domestic action and international cooperation in this regard. With respect to augmenting financial support for export and investment transactions in LCT S, cooperation encompasses issues that are beyond the subject-matter scope of the wTо. Therefore, ideally, efforts should be made under the auspices of the climate regime to highlight the expected role of the trade regime. Commitments to reduce distortive subsidies promoting polluting activities (e.g. subsidies on coal and petroleum), made individually or different multiparty setting will also prove useful. 